Bangladesh J. Bot. 44(3): 399-405, 2015 (September)

\title{
MULTIVARIATE ANALYSIS OF ENVIRONMENT-VEGETATION COMPLEX OF VEHARI DISTRICT, PAKISTAN
}

\author{
Arifa Zereen* and AndleEb AnWar Sardar ${ }^{1}$ \\ University of Education, Bank Road Campus, Lahore, Pakistan
}

Key words: Multivariate analysis, Plant Classification, Soil, Water

\begin{abstract}
Multivariate analysis using two-way indicator species analysis (TWINSPAN) and Canonical correspondence analysis (CCA) were used to classify the phytosociology of the District Vehari, Pakistan. A total of 35 plant species belonging to 23 families were recorded. The first level TWINSPAN divided the vegetation of entire study area into two major communities which were subsequently separated into subcommunities. Each major and sub-community was named following the most important dominant species. CCA identified the relationship of vegetation structure to specific environmental factors. This relationship was studied by CANOCO analysis. In the CCA of all the species for Vehari, soil $\mathrm{pH}$ and water $\mathrm{pH}$ and EC were the most important variables influencing the species distribution. This survey offers key information regarding vegetation and would be helpful for the conservation of biodiversity of the area under study.
\end{abstract}

\section{Introduction}

Vehari is a model of arid hot sub-tropical monsoon region and situated in $30^{\circ} 01^{\prime} 453^{\prime \prime} \mathrm{N}$ $72^{\circ} 52^{\prime} 189^{\prime \prime} \mathrm{E}$. It is about $100 \mathrm{~km}$ from the metropolis of Multan and about $25 \mathrm{~km}$ north of the river Sutlej. The sampling area extends over $4364 \mathrm{~km}^{2}$ of the Subrecent and Recent floodplains of Sutlej and Bias Rivers. It has very deep, well drained, dominantly silty and loamy soils highly suitable for a wide variety of plants or crops (Zereen 2008).

The present research was carried out to enumerate the vegetation in Vehari district by employing ordination techniques and to evaluate various edaphic and hydrological parameters of the study area that could affect the relationship of soil, water and vegetation. There is utmost need for biological assessment and to classify the vegetation of the area in order to conserve the natural environment for future benefits (Agosti et al. 2000, Shahbaz et al. 2007). For this purpose twoway indicator species analysis (TWINSPAN), which is multivariate technique for vegetation data analysis was used (Graveson 2009, Hill 1979).

Using TWINSPAN, Kim (2013) identified 275 species belonging to 63 families of vascular plants and identified 6 communities in the area. Ahmad et al. (2013) carried out the multivariate analysis of the roadside vegetation along Motorway (M-1), Pakistan. TWINSPAN divided the whole flora of the area into two major and fourteen sub-communities. Ahmad et al. (2014) analyzed the vegetation data of Changa Manga Park Lahore, Pakistan by TWINSPAN analysis and identified 45 species belonging to 24 families in four zones of the forest.

Most recent development in ordination techniques is Canonical Correspondence Analysis (CCA) developed by Ter Braak (1988). CCA incorporates the correlation and regression between floristic data and environmental factors within the ordination analysis itself. Thus input to CCA consist of not just a data matrix of species $\mathrm{x}$ quadrat but a second data matrix of environmental variables x quadrats (Kent and Coker 1995). Resulting ordination diagram thus expresses not only patterns of variations in floristic composition but also demonstrates the principal relationships between the species and each of the environmental variables (Kashian et al. 2003).

*Author for correspondence: <arifazereen@yahoo.com>. 'Department of Botany, Govt. College University, Lahore, Pakistan. <aainasrdr@gmail.com>. 
Ahmad and Huma (2011) used CCA to find out the relation of vegetation structure and some environmental factors. It was found that $\mathrm{pH}$, soil organic matter and soil water content were the elements that influence the herbaceous vegetation growth. Ahmad (2012) conducted a study at Ayubia National Park Rawalpindi, Pakistan to find out the species response and correlation with environmental factors. The park was divided into two zones and the data were analyzed by CCA. Khan et al. (2013) used CCA to determine the response of species to moisture stress in different zones of Changa Manga Forest. Ahmad et al. (2014) carried out a study at Korang river, Islamabad to determine vegetation and soil relationships and associations. About 21 species belonging to 14 families were identified.

\section{Materials and Methods}

Extensive floristic and vegetational surveys of the area were carried out in early spring and late summer. The study included inventorying of natural flora through detailed survey of each site with specimen collection, phytosociological analysis using quadrat method, observations on threats to biodiversity and ecosystem in each site. The collected specimens were identified with the help of Flora of Pakistan (Nasir and Ali 1970-1989, Ali and Nasir 1990-1992 and Ali and Qaisar 1992-2010). The voucher specimens were deposited in Dr. Sultan Herbarium, Botany Department, GC University, Lahore, Pakistan.

Field vegetation parameters i.e., percentage cover and frequency were recorded (Kent and Coker 1992) and sampling was carried out by using quadrat of $1 \mathrm{~m}^{2}$ for grasses, $5 \mathrm{~m}^{2}$ for shrubs and $10 \mathrm{~m}^{2}$ for trees following Braun-Blanquet approach. The phytosociological data were analyzed by two-way indicator species analysis (TWINSPAN) software and environmental data by CCA. Composite soil samples were taken at $0-15 \mathrm{~cm}$ depth. These samples were analyzed to determine physical (soil texture, colour, soil moisture content) and chemical parameters like EC and $\mathrm{pH}$ following standard procedures. Likewise collected ground water samples were recorded for their $\mathrm{pH}, \mathrm{EC}$ and water table depth. The major threats to the ecosystem were recognized as pollution, agricultural fields, alien invasive species and overgrazing by livestock.

\section{Results and Discussion}

Vegetation assessment was carried out in different seasons. The percentage cover data were compiled using Microsoft Excel programme spreadsheets. These values were then analyzed by using TWINSPAN software.

The result of the study was splited into two parts are discussed as under: First part describes the results of plant species analysis utilizing TWINSPAN and second part describes the results of CCA analysis of vegetation.

TWINSPAN classification of species at Vehari. A total of 35 species related to 23 families were documented from 50 quadrats in Vehari study area. These results show clearly that at first level TWINSPAN divided the vegetation of entire study area into two major communities which were subsequently separated into sub-communities. Each major and sub- community was named following the most important dominant species (Fig.1). Abbreviations for the plant species mentioned in Figs 1 and 2 are listed in Table 1.

Major community 1: Alhagi maurorum and Eucalyptus citriodora. The major community 1 was not divided further into sub-communities as it consists of only eight species. 
TWINSPAN Vehari District

Matrix Coding

$\square$ Presence $\square$ Absence

Information Remaining (\%)

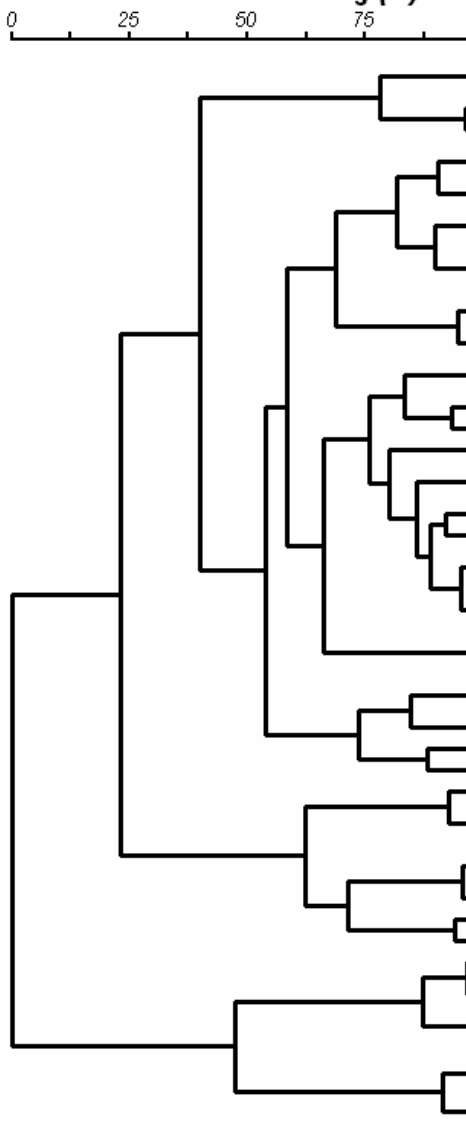
100

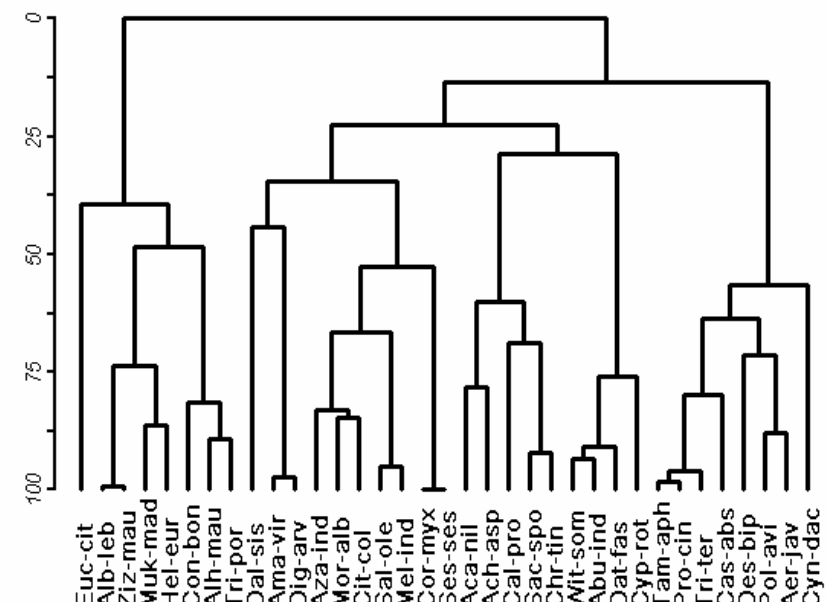

Sample0

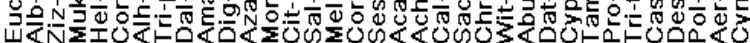

- Sample11

Sample 02

Sample02

Sample12

Sample1

Sample30

Sample03

Sample23

Sample1

- Sample4 40

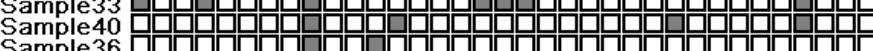
Sample 36 un

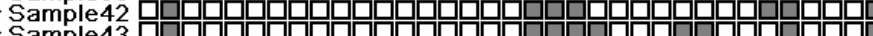

Sample43 प्र

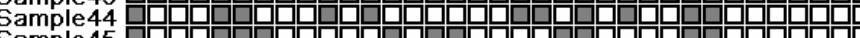

Sample45

c Sample49 品品品

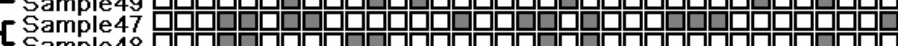

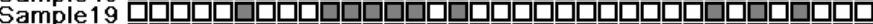

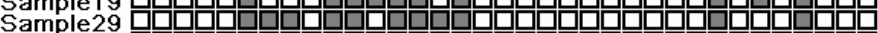

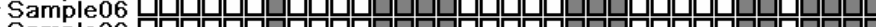

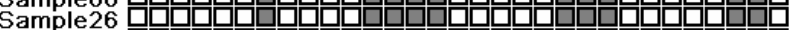

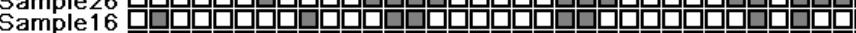

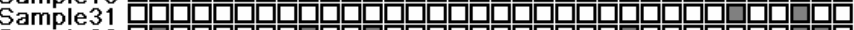

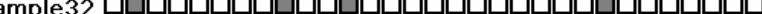

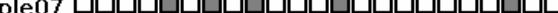

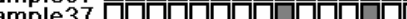

Sample38

-1 Sample08

Sample28

Sample09

Sample39

[Sample14

Sample24

Sample05

Sample25

Sample35

Fig. 1. TWINSPAN analysis of species at Vehari district. 


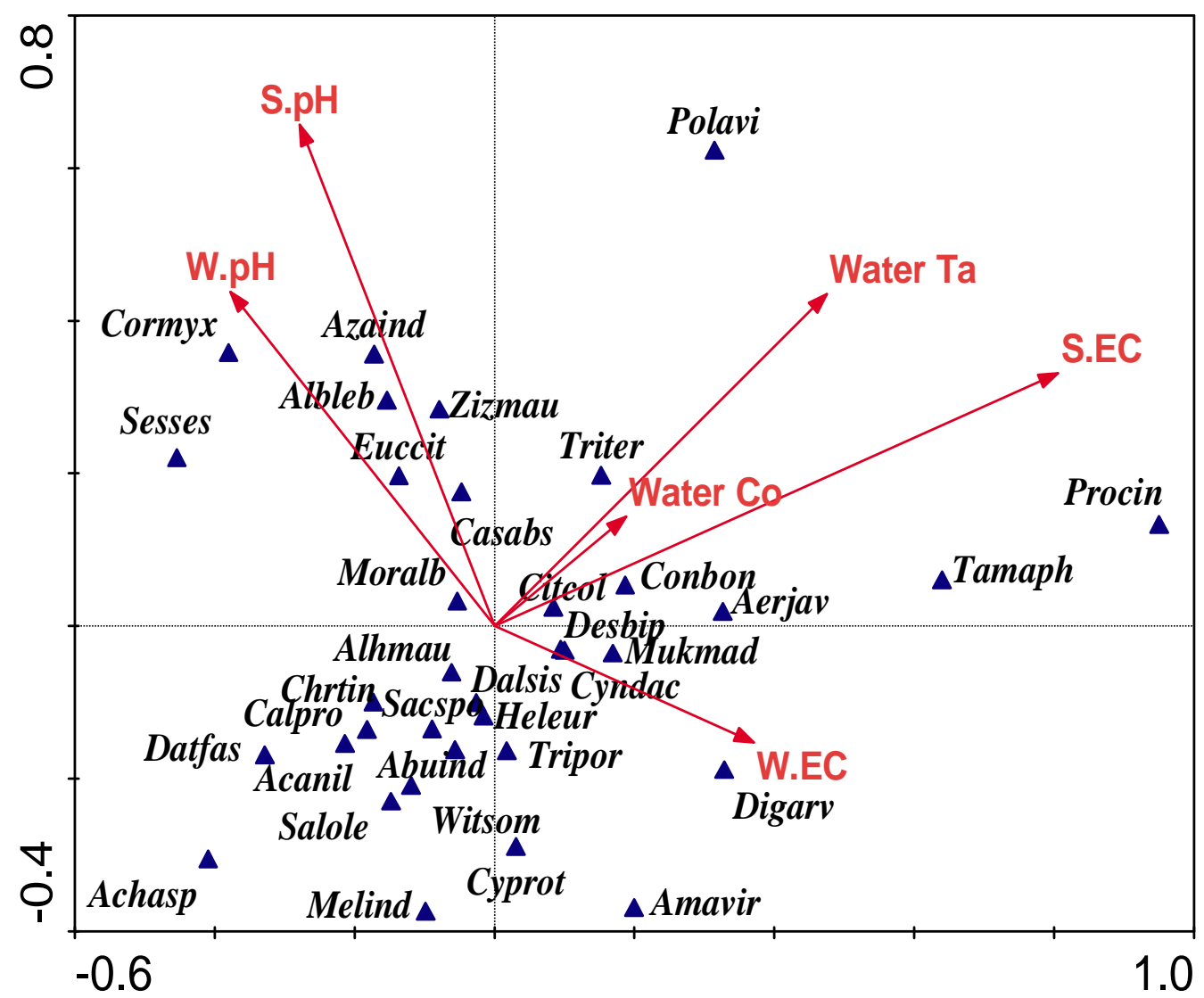

Fig. 2. Biplot diagram of species and environmental variables for Vehari.

Major community 2: Calotropis procera and Desmostachya bipinnata. The diagnostic species of this community were A. maurorum and E. citriodora with frequency values of 50 and $37.5 \%$, respectively. The other members of this community included Albizia lebbeck, Ziziphus mauritiana, Mukia maderaspatana, Heliotropium europaeum and Conyza bonariensis. This major community was recorded from the quadrats studied in the Railway waste yards and the dominant species also exhibited a fairly good percentage cover values. This sub-community was a mixture of herb and tree species. The community seemed to be grouped together due to similar ecological and microhabitat requirements.

Major community 2 was further divided into following sub-communities: Dalbergia sissoo and Morus alba, Calotropis procera and Saccharum spontaneum, Desmostachya bipinnata and Tribulus terrestris.

\section{Dalbergia sissoo and Morus alba}

This sub-community marked its appearance along roads, rail sides and canals as linear plantation in the Head Ludan study area. These were even retained in the agriculture fields for shade purposes. The farmers in Punjab have been planting Dalbergia sissoo since decades in linear form around the fields. While Morus alba, commonly known as white mulberry can be 
weedy or invasive some times. $M$. alba usually establishes along roads, old cultivated fields, forest margins, urban areas, and disturbed areas. Both the plants were under great cutting and browsing pressure. (http://www.issg.org/database/species/ecology.asp?si=1559\&fr=1\&sts=\&lang=EN).

Table 1. Elaborated names of plant species presented in Figs 1 and 2.

\begin{tabular}{lll}
\hline $\begin{array}{l}\text { S1. } \\
\text { No. }\end{array}$ & $\begin{array}{l}\text { Abbrevia- } \\
\text { tions }\end{array}$ & Species \\
\hline 1. & Abu-ind & Abutilon indicum \\
2. & Aca-nil & Acacia nilotica \\
3. & Ach-asp & Achyranthes aspera \\
4. & Aer-jav & Aerva javanica \\
5. & Alb-leb & Albizia lebbeck \\
6. & Alh-mau & Alhagi maurorum \\
7. & Ama-vir & Amaranthus viridis \\
8. & Aza-ind & Azadirachta indica \\
9. & Cal-pro & Calotropis procera \\
10. & Cas-abs & Cassia absus \\
11. & Chr-tin & Chrozophora tinctoria \\
12. & Cit-col & Citrullus colocynthis \\
13. & Con-bon & Conyza bonariensis \\
14. & Cor-myx & Cordia myxa \\
15. & Cyn-dac & Cynodon dactylon \\
16. & Cyp-rot & Cyperus rotundus \\
17. & Dal-sis & Dalbergia sissoo \\
18. & Dat-fas & Daturafastuosa \\
\hline & &
\end{tabular}

\begin{tabular}{lll}
\hline $\begin{array}{l}\text { Sl. } \\
\text { No. }\end{array}$ & $\begin{array}{l}\text { Abbrevia- } \\
\text { tions }\end{array}$ & Species \\
\hline 19. & Des-bip & Desmostachya bipinnata \\
20. & Dig-arv & Digitaria arvensis \\
21. & Euc-cit & Eucalyptus citriodora \\
22. & Hel-eur & Heliotropium europaeum \\
23. & Mel-ind & Melilotus indica \\
24. & Mor-alb & Morus alba \\
25. & Muk-mad & Mukia maderaspatana \\
26. & Pol-avi & Polygonum aviculare \\
27. & Pro-cin & Prosopis cineraria \\
28. & Sac-spo & Saccharum spontaneum \\
29. & Sal-ole & Salvadora oleoides \\
30. & Ses-ses & Sesbania sesban \\
31. & Tam-aph & Tamarix aphylla \\
32. & Tri-por & Trianthema portulacastrum \\
33. & Tri-ter & Tribulus terrestris \\
34. & Wit-som & Withania somnifera \\
35. & Ziz-mau & Ziziphus mauritiana \\
& & \\
\hline
\end{tabular}

Table 2. List of abbreviations used in Fig. 2.

\begin{tabular}{lll}
\hline Sl.No. & Abbreviations & Expansion \\
\hline 1. & W. $\mathrm{pH}$ & Water $\mathrm{pH}$ \\
2. & Water Co & Water content \\
3. & W. EC & Water electric conductivity \\
4. & Water Ta & Water Table \\
5. & S. EC & Soil electric conductivity \\
6. & S. pH & Soil pH \\
\hline
\end{tabular}

\section{Calotropis procera and Saccharum spontaneum}

The sub-community $C$. procera and $S$. spontaneum were found in waste lands and disturbed habitat along the road leading from Vehari to Hasilpur. Both the species showed very small percentage cover values i.e., S. spontaneum $13.2 \%$ and C. procera $8.16 \%$. This herbaceous group made a significant growth in waste habitats or areas. C. procera grows vigorously whereever waste lands and disturbed areas are available. That is why it is considered as indicator of waste land (www.Tncweed.ucdavis.edu/esodocs.documents.html). 
Whereas S. spontaneum is found growing in small clumps accumulating sand around it. Signs of grazing were evident and large clumps of plants cut at ground level also indicated human interference. Both species propagate quickly by seeds and require same conditions for their survival.

\section{Desmostachya bipinnata and Tribulus terrestris}

The diagnostic species of community, D. bipinnata and T. terrestris, exhibited fairly good frequency values i.e., 60 and $47.5 \%$, respectively. This community made its appearance mostly in the waste lands and along road margins leading to Rakh Jumlara and in the Rakh Jumlara forest itself. D. bipinnata is a grass of exposed and dry places, covering open ground. The presence of this plant is an indicator of moisture present in the deeper layers of soils. Its roots penetrate in the deeper layers of soils to absorb moisture. In this plant the roots are approximately three to eight times longer than the aerial parts (Chaghtai et al. 1989). The co-dominant member of this community T. terrestris is considered as a noxious weed (Nasir and Rafique 1995). It was found growing in association with D. bipinnata in dry sandy soils in the study area. It propagated quickly by seeds, and require hot climate for flourishing. The associated species of this group were Cynodon dactylon, Aerva javanica and Tamarix aphylla. The total number of species of this subcommunity was eight.

\section{Biplot diagram of species and environmental variables for Vehari}

The parameters selected to identify the relationship between species and environmental variables were $\mathrm{EC}, \mathrm{pH}$ and soil water content as soil variables and $\mathrm{EC}, \mathrm{pH}$ and water table depth as water variables (Table 2). In Fig. 2 the small triangular points represent the species whereas the arrows indicate different environmental variables. The variables with longer arrows had more significant influence on plant communities' distribution and variation. The angle between an arrow and its axis was an indication of its degree of correlation with that axis (Farrag 2012). The species nearest the arrow head were more strongly influenced by the environmental factor represented by that arrow, compared to the species farthest from the arrow head. The closer the points to each other the greater is their degree of similarity. If several species exist on the same point, it means their abundance was same and they are being influenced in same way by that particular environmental gradient (Bruelheide and Udelhoven 2005).

In the CCA biplot of Vehari most of the species were clustered around the center of the biplot diagram (Fig. 2) indicating a lack of any definite grouping of vegetation into major communities or sub- communities. This was due to the fact that no environmental variable was performing a pronounced role in grouping of species. Biplot diagram of species and environmental factors showed strong correlation with reference to distribution of different species along axis 1 . In the CCA of all the species for Vehari, soil and water $\mathrm{pH}$ and water EC were the most important variables influencing the species distribution. Over all soil $\mathrm{pH}$ exhibited correlation in the distribution of Azadirachta indica, Albizia lebbeck and Ziziphus mauritiana. While distribution of Cordia myxa and Eucalyptus citriodora were more strongly influenced by water $\mathrm{pH}$ along axis 2. Similarly, Digitaria arvensis was showing strong correlation with water EC indicating this species is strongly influenced by this environmental variable. Whereas water table and soil EC exhibited no significant correlation and therefore performed no significant function in the distribution of species along the two axes. 


\section{References}

Agosti D, Majer JD, Alonso LE and Schultz TR. 2000. Ants: Standard method for measuring and monitoring biodiversity. Smithsonian press, Washington D.C., 280.

Ahmad SS 2012. Species response to environmental variables in Ayubia National Park, Pakistan using multivariate analysis. Pak. J. Bot. 44(4): 1225-1228.

Ahmad SS, Erum S, Khan SM and Nawaz M 2014. An appraisal of ecological distribution of herbaceous flora at Changa Manga Park Lahore, Pakistan. Pak. J. Bot. 46: 19-25.

Ahmad SS and Huma E 2011. Canonical correspondence analysis of Lohi Bher (Wildlife Park) herbaceous vegetation. J. Int. Env. Appl. \& Sci. 6(3): 365-370.

Ahmad SS, Khan S and Erum S 2013. Multivariate analysis of roadside vegetation along motorway (M-1), Pakistan. Pak. J. Bot. 45(1): 49-53.

Ahmad SS, Murtaza R, Shabir S and Ahmed MN, Shah TA 2014. Environmental diversification and spatial variations in riparian vegetation: A case study of Korang River, Islamabad. Pak. J. Bot. 46(4): 12031210.

Ali SI and Nasir YJ 1990- 92. Flora of Pakistan. Vol. 191-193, Department of Botany, University of Karachi and National Herbarium, PARC, Islamabad.

Ali SI and Qaiser M 1992- 2010. Flora of Pakistan. Vol. 194-208, Department of Botany, University of Karachi and National Herbarium, PARC, Islamabad.

Bruelheide $\mathrm{H}$ and Udelhoven P 2005. Correspondence of the fine-scale spatial variation in soil chemistry and the herb layer vegetation in beech forests. Forest Ecol. Manag. 210: 205-223.

Chaghtai SM, Shah SZ and Shah J 1989. Temporal changes in vegetation of Miranjani Top Galis, Hazara, NWFP, Pakistan. Pak. J. Bot. 21: 107-117.

Farrag HF 2012. Floristic composition and vegetation-soil relationships in Wadi Al-Argy of Taif region, Saudi Arabia. Int. Res. J. Plant Sci. 3(8): 147-157.

Graveson R 2009. The classification of the vegetation of Saint Lucia FCG (Finnish Consultancy Group) International Ltd. Helsinki, Finland.

Hill MO. 1979. TWINSPAN, A FORTAN program for arranging multivariate data in an ordered two-way table by classification of the individuals and the attributes. Cornell University, Department of Ecology and Systematic, Ithaca, New York.

Kashian DM, Barnes BV and Walker WS 2003. Ecological species groups of land form- level ecosystems dominated by Jack Pine in northern Lower Michigan, USA. Plt. Ecol. 166: 75-91.

Kent M and Coker P 1992. Vegetation description and analysis. 1st ed. Bilhaven Press, London.

Kent M and Coker P 1995. Vegetation description and analysis. 2nd ed. John Wiley and Sons, Chichester.

Khan SM, Ahmad SS, Erum S, Wahid A, Nawaz M 2013. An assessment of vegetation dominance against moisture stress in Changa Manga Forest Pak. J. Bot. 45(6): 1939-1944.

Kim KD 2013. Vegetation dynamics on waste landfills in the Seoul metropolitan area. Int. J. Env. Res. 7(3): 801-806.

Nasir E and Ali SI 1970-89. Flora of Pakistan. Vol. 1-190, National Herbarium, PARC,Islamabad and Department of Botany, University of Karachi, Pakistan.

Nasir YJ and Rafique RA 1995. Wild Flowers of Pakistan. T. J. Roberts, Oxford University Press, Karachi.

Shahbaz B, Ali T and Suleri AQ 2007. A critical analysis of forest policies of Pakistan: Implications for sustainable livelihoods. Mitig. Adapt. Strat. Gl. 12(4): 441-453.

Ter Braak CFJ 1988. CANOCO-a FORTRAN Program for canonical community ordination by (partial) (detrended) (canonical) (correspondence) analysis (Version 2.0). TNO Institute of Applied Computer Science, Wageningen.

Zereen A 2008.Ethnoecological studies of wild flora of central Punjab, Pakistan. Ph.D. dissertation. GC University, Lahore.

Web sites: http://www.issg.org/database/species/ecology.asp?si=1559\&fr=1\&sts=\&lang=EN; www. Tncweed. ucdavis.edu/esodocs.documents.html 